\title{
PERTANGGUNGJAWABAN PIDANA TERHADAP TINDAK PIDANA PENYEBARAN VAKSIN PALSU OLEH PETUGAS FARMASI PADA MASYARAKAT (Studi Putusan Nomor 1508/Pid.Sus/2016/PN Bks)
}

\author{
Ricky \\ Frans Gerhard Silalahi \\ Fakultas Hukum Universitas Prima Indonesia \\ Jalan Sekip Simpang Sikambing, Medan, Sumatera Utara \\ fransilalahi@gmail.com
}

\begin{abstract}
Health is an important thing for a country because health is one of the parameters to measure the success of human development. The purpose of this study was to determine the legal arrangements, government efforts, legal protection regarding the use of vaccines, tackling and spreading fake vaccines. The method used in this study is a normative juridical method which is analytical descriptive, the source of legal material obtained is using secondary data consisting of primary, secondary and tertiary legal materials, data collection techniques using data collection techniques by means of library and data analysis in a manner quantitative and systematically presented. Based on the results of this study the legal arrangements regarding the use of vaccines in the community are contained in the Health Law No. 36 of 2009, and are regulated in the Minister of Health Regulation of the Republic of Indonesia No. 12 of 2017 concerning the Implementation of Immunization under this consideration. Based on the facts in the trial of evidence, then in the trial of the judge who believes that the defendant's actions violated article 197 UUN. 36 of 2009, then in the trial the defendant was found guilty of committing the crime of spreading fake vaccines which is an appropriate act.
\end{abstract}

Keywords: Fake Vaccines, Criminal Liability, Criminal Acts.

\section{Pendahuluan}

\subsection{Latar Belakang}

Kesehatan merupakan suatu hal yang sangat penting dalam mengukur laju pertumbuhan suatu bangsa serta mempunyai peranan mendasar dalam menciptakan masyarakat adil, makmur, dan sejahtera. Kesehatan merupakan unsur mendasar bagi kesejahteraan umum yang wajib di wujudkan sesuai dengan cita-cita bangsa Indonesia yang dituangkan dalam pembukaan UUD Negara Kesatuan RI 1945 dalam rangkaian pembangunan nasional yang berkesinambungan berpedoman pada Pancasila dan UUD NKRI 1945. Derajat kesehatan sangat penting bagi perkembangan dan pembinaan SDM serta merupakan modal 
utama bagi pelaksanaan pembangunan nasional yang pada dasarnya membangun manusia seutuhnya. ${ }^{1}$

Berdasarkan hal tersebut, upaya kesehatan merupakan suatu kegiatan yang dilakukan guna memelihara dan meningkatkan kesehatan yang dilakukan oleh pemerintah dan bisa juga masyarakat melalui jasa tenaga. Kewenangan dalam menjalankan upaya-upaya dalam hal kesehatan inilah yang harus memiliki dasar hukum yang pasti dalam mengaturnya. Landasan hukum dalam upaya kesehatan saja belum mumpuni mengingat dalam menjalankan upayaupaya kesehatan harus dilengkapi dengan sumber daya kesehatan baik yang berupa perangkat keras maupun perangkat lunak. ${ }^{2}$

Kini dunia seakan tanpa berbatas. Begitu mudah orang-orang melakukan perjalanan ke luar negeri, entah untuk tujuan pendidikan, bekerja, travelling, atau menunaikan ibadah haji. Paling tidak saat ini ada satu miliar wisatawan melakukan perjalanan melalui udara dan 50 juta orang meakukan perjalanan ke negara berkembang. Mereka semua beresiko mendapatkan infeksi yang dapat dicegah melalui Vaksinasi. ${ }^{3}$

Oleh karena permasalahan tersebut, penulis mencoba untuk menuliskan permasalahan hukum dengan judul: "Pertanggungjawaban Pidana Terhadap Tindak Pidana Penyebaran Vaksin Palsu Oleh Petugas Farmasi Pada Masyarakat Di Kota Bekasi (Studi Putusan Nomor 1508/Pid.Sus/2016/PN Bks)". Dimana berdasarkan hal tersebut, penulis ingin mengetahui bagaimana pengaturan hukum tentang penggunaan vaksin di masyarakat, upaya pemerintah dalam menanggulangi vaksin palsu yang terjadi di masyarakat, serta perlindungan hukum terhadap penyebaran vaksin palsu yang ada di masyarakat.

Agar di peroleh manfaat baik teori maupun praktik yaitu secara teoritis dapat memberikan masukan serta manfaat di bidang akademis sehingga pengetahuan tentang Aturan Penggunaan Vaksin khususnya Terkait dengan Hukum Kesehatan menjadi lebih baik dari sebelumnya baik bagi masyarakat, pengajar, bahkan praktisi dan secara praktis dapat di jadikan sebagai pedoman dan bahan evaluasi bagi pemerintah dan kementrian atau dinas kesehatan sendiri, serta rumah sakit sebagai bahan untuk mencari solusi terhadap penyebaran vaksin palsu dan sebagai evaluasi untuk memperkuat aturan-aturan hukum terkait penggunaan dan penyebaran vaksin, serta harapkan dapat memberikan masukan-masukan sera wawasan dan pemikiran yang baru bagi masyarakat mengenai pengetahuan tentang Hukum Kesehatan Khususnya mengenai aturan hukum terkait penggunaan dan penyebaran vaksin.

\subsection{Kerangka Teori dan Konsepsi a. Kerangka Teori}

Teori yang dipergunakan dalam penelitian ini adalah teori pertanggung jawaban pidana. Roeslan Saleh menyampaikan bahwa pertanggung jawaban pidana yaitu sebagai keterusan celaan yang objektif yang ada pada perbuatan pidana dan secara subjektif memenuhi atau dengan kata lain suatu kondisi dimana terpenuhinya suatu syarat-syarat untun

\footnotetext{
${ }^{1}$ Maskawati dan Andriani Misdar, "Hukum Kesehatan Dimens Etis dan Yuridis Tanggung jawab Pelayanan Kesehatan”, Pertanggungjawaban Pidana terhadap Tindak Pidana penyebaran vaksin palsu pada masyarakat, Jurnal Unpad, No. 12, hal. 1, 2018.

${ }^{2}$ Hendrik, Etika \& Hukum Kesehatan, Nuha Medika, Jakarta, 2011, hal 27.

${ }^{3}$ J.B. Suharjo B. Cahyono, Vaksinasi Cara Ampuh Cegah Penyakit Infeksi, Kanisius, Yogyakarta, 2018 , hal 9.
} 
meminadai seseorang yang telah melakukan suatu kejahatan yang melanggar hukum di Indonesia. Apa yang dimaksud dengan celaan objektif adalah sesuatu yang sudah di perbuat oleh seseorang tersebut merupakan perbuatan yang tidak diperkenankan, perbuatan tidak diperkeenankan yang dimaksud disini adalah perbuatan yang memang bertentangan atau tidak diperkenankan oleh hukum formil maupun hukum materil. Sedangkan yang dimaksud dengan celaan subjektif menyangkut kepada sipembuat perbuatan yang tidak diperkenankan tersebut, atau dapat dikatakan celaan yang subjektif adalah orang yang melakukan perbuatan yang tidak diperkenankan atau tidak selaras dengan hukum. Apabila perbuatan yang dilakukan suatu perbuatan yang cacat atau suatu perbuatan yang tidak diperkenankan atau tidak diperbolehkan namun apabila didalam diri seseorang tersebut ada kesalahan yang yang menyebabkan tidak dapat bertanggungjawab maka pertanggungjawaban pidana tersebut tidak mungkin ada. ${ }^{4}$

\section{b. Konsepsi}

a. Pertanggungjawaban Pidana adalah suatu cara kerja untuk menetapkan apakah seseorang terdakwa ataupun tersangka dapat dipertanggungjawabkan atas suatu tindakan pidana yang telah terjadi atau tidak. ${ }^{5}$

b. Tindak Pidana adalah suatu perbuatan yang tidak sesuai atau melanggar suatu aturan hukum atau perbuatan yang dilarang oleh aturan hukum yang disertai dengan sanksi pidana yang mana aturan tersebut ditujukan kepada perbuatan sedangkan ancamannya atau sanksi pidananya ditujukan kepada orang yang melakukan atau orang yang menimbulkan kejadian tersebut. ${ }^{6}$

c. Penyebaran adalah Proses atau cara, perbuatan menyebar atau menyebarkan. ${ }^{7}$

d. Vaksin adalah suatu zat yang merupakan suatu bentuk produk biologi yang diketahui berasal dari virus, bakteri atau dari kombinasi antara keduanya yang dilemahkan dan diberikan kepada individu yang sehat guna merangsang munculnya antibody atau kekebalan tubuh guna mencegah dari infeksi penyakit tertentu. ${ }^{8}$

e. Masyarakat adalah sekelompok orang yang membentuk sebuah sistem semi tertutup (atau semi terbuka), dimana sebagian besar interaksi adalah antara individu-individu yang berada dalam kelompok tersebut.

\section{Metode Penelitian}

\subsection{Jenis dan Sifat Penelitian.}

Jenis penelitian yang digunakan pada penelitian ini adalah yuridis normatif yang bersifat deskriptif analitis dimana mampu memaparkan fakta dan menjelaskan fakta-fakta tersebut berdasarkan hasil penelitian objek atau suatu peristiwa yang sudah terjadi. Jenis penelitian yuridis normatif merupakan pendekatan yang dilakukan atau ditujukan hanya pada peraturan-peraturan yang tertulis atau bahan-bahan hukum yang lain.

\subsection{Sumber Bahan Hukum}

\footnotetext{
${ }^{4}$ Roeslan Saleh, Pikiran-Pikiran Tentang Pertanggung Jawaban Pidana, Cetakan Pertama, Jakarta, Ghalia Indonesia, hal 33.

${ }^{5}$ Agus Rusianto, Tindak Pidana dan Pertanggung jawaban Pidana, Kenana, Jakarta, 2016, hal 221

${ }^{6}$ Ibid, hal 38.

${ }^{7}$ Kamisa, Kamus Besar Bahasa Indonesia, Cahaya Agency, Surabaya, 2012, hal 432.

${ }^{8}$ Ahmad Ramali dan Pamoentjak, Kamus Kedokteran, Erlangga, Jakarta, 2005, hal 632.
} 
Sumber bahan hukum yang digunakan dalam penelitian ini adalah data sekunder. Data sekunder tersebut dapat dibagi menjadi:

a. Bahan Hukum Primer

Bahan-bahan hukum yang mengikat terdiri dari peraturan perundang-undangan yang terkait dengan objek penelitian, seperti Undang-Undang No 1 Tahun 1946 Tentang Peraturan Hukum Pidana atau Kitab Undang-Undang Hukum Pidana., Undang-Undang Nomor 36 Tahun 2009 tentang Kesehatan Putusan Nomor 1508/Pid.Sus/2016/Pn Bks, dan Peraturan Perundang-undangan lainnya yang terkait dengan Penelitian ini.

b. Bahan Hukum Sekunder

Bahan hukum sekunder terdiri dari buku-buku cetak, jurnal penelitian, tulisan-tulisan ilmiah hukum, serta yang terkait dengan objek penelitian ini.

c. Bahan Hukum Tersier

Bahan Hukum tersier merupakan petunjuk atau penjelasan mengenai bahan hukum primer atau bahan hukum sekunder yang berasal dari kamus, ensiklopedia, majalah, surat kabar, dan lain sebagainya.

\subsection{Teknik Pengumpulan Data}

Untuk memperoleh suatu kebenaran ilmiah dalam penulisan sebuah jurnal, perlu digunakan teknik pengumpulan data dengan cara studi kepustakaan, hal ini dilakukan dengan mempelajari dan menganalisis segala hal yang berkaitan dengan topik penelitian. Sumbersumber kepustakaan dapat diperoleh dari Buku-buku cetak, Jurnal penelitian, Makalah, Internet, Peraturan perundang-undangan dan bahan-bahan lain yang berhubungan dengan materi yang di bahas dalam jurnal penelitian ini.

\subsection{Analisis Data}

Metode yang digunakan dalam menganalisis data penelitian ini adalah menggunakan analisis kuantitatif, dimana data yang diperoleh kemudian disusun secara sistematis dan selanjutnya di analisis secara kuantitatif guna mencapai kejelasan masalah yang akan dibahas, lalu hasil tersebut dituangkan dalam bentuk jurnal. Metode kuantitatif dilakukan untuk mendapatkan data yang bersifat deskriftif yaitu berupa data-data yang akan di teliti dan dipelajari dalam bentuk yang utuh.

\section{Pembahasan}

\subsection{Pengaturan Hukum Tentang Penggunaan Vaksin Di Masyarakat}

Vaksin merupakan suatu produk biologik yang terbuat dari bakteri/kuman, komponen kuman/racun kuman yang telah dilemahkan atau dimatikan yang dapat untuk digunakan untuk merangsang timbulnya kekebalan tubuh pada seseorang manusia ataupun makhluk hidup. Pada pasal 28H Undang-Undang Dasar Negara Republik Indonesia Tahun 1945 dinyatakan bahwa setiap orang berhak hidup sejahtera lahir dan batin, memiliki tinggal dan mendapatkan lingkungan hidup layak dan sehat serta berhak memperoleh pelayanan kesehatan yang mumpuni. Berdasarkan Undang-Undang Nomor 36 Tahun 2009 tentang Kesehatan menegaskan bahwa kesehatan rakyat merupakan salah satu modal pokok dalam rangka pertumbuhan dan kehidupan bangsa, serta memiliki peranan yang penting dalam penyusunan masyarakat adil, makmur, dan sejahtera. Sebagai pemerintah yang baik dan 
bertanggung jawab, pemerintah wajib atau berinisiatif memberikan imunisasi atau vaksinasi yang lengkap kepada setiap bayi dan anak-anak sebagaimana dijelaskan dalam UU Kesehatan Nomor 36 Tahun 2009. Bagi yang melanggar harus dikenakan sanksi. Adapun mengenai aturan pelaksana pemberian vaksin atau imunisasi di atur di dalam Peraturan Menteri Kesehatan Republik Indonesia Nomor 12 Tahun 2017 Tentang Penyelenggaraan Imunisasi. ${ }^{9}$

\subsection{Upaya Pemerintah Dalam Menanggulangi Vaksin Palsu Yang Terjadi Di Masyarakat}

Badan Pengawas Obat dan Makanan atau di singkat dengan BPOM mempunyai tanggung jawab yang penuh terhadap keadaan, kegunaan, dan mutu vaksin yang beredar luas di seluruh wilayah di Republik Indonesia. Oleh karena itu, Badan Pengawas Obat dan Makanan atau di sebut juga BPOM harus melakukan penjagaan yang ketat dan pemeriksaan terkait obat-obatan khususnya vaksin yang akan beredar di masyarakat luas. Adapun terkait peredaran vaksin palsu tersebut, maka BPOM merupakan lembaga yang wajib bertanggung jawab terhadap pengawasan peredaran vaksin yang ada di pasaran hingga sampai ke masyarakat. Bentuk-bentuk pengawasan tersebut adalah dengan mengadakan razia maupun sidak langsung pada apotek yang menjual vaksin serta memperketat izin distributor maupun perusahaan pembuat vaksin itu sendiri. ${ }^{10}$

Berdasarkan hal tersebut, Badan Pengawas Obat dan Makanan (BPOM) dalam upayanya melakukan tugas, fungsi, dan wewenang harus sesuai dengan perundang-undangan yang mengaturnya. Tugas BPOM berdasarkan Pasal 67 Keputusan Presidan Nomor 103 Tahun 2001 yaitu, BPOM melakukan tugas pemerintah di bidang pengawasan Obat dan Makanan sesuai dengan ketentuan peraturan perundang-undangan yang berlaku. Wewenang dari BPOM diatur berdasarkan Pasal 67 Keputusan Presiden Nomor 103 Tahun 2001.

Dalam melakukan pengawasannya BPOM menggunakan dua langkah, yaitu Pre Market Control dan Post Market Control. Pre Market Control merupakan pengawasan yang dilakukan sebelum produk obat-obatan dan makanan tersebut diedarkan dimasyarakat. Post Market Control merupakan pengawasan yang dilakukan terhadap produk obat-obatan dan makanan yang telah beredar dipasaran atau telah sampai di masyarakat. Pengawasan yang dilakukan oleh BPOM sudah terstruktur dengan baik, namun demikian selama masih ada pelaku kriminal pembuat vaksin palsu serta masih adanya permintaan vaksin di luar program pemerintah maka kemungkinan masih tersedianya vaksin palsu di sarana kesehatan dan pelayanan kesehatan ${ }^{11}$.

\subsection{Perlindungan Hukum Terhadap Penyebaran Vaksin Palsu Yang Ada Di Masyarakat}

Undang-Undang Nomor 36 Tahun 2009 Tentang Kesehatan mengatur terkait sanksi pidana terhadap pelaku atau industrI farmasi yang mengedarkan atau membuat vaksi palsu, yaitu di atar pada pasal 196 UU No 36 Tahun 1999 tentang kesehatan.

\footnotetext{
${ }^{9}$ Jurnal Kementrian Kesehatan, Kewajiban Negara Memberikan Vaksinasi dan Imunisasi, Vol 1 No 2, 2012, hal 3.

${ }^{10} \mathrm{Ibid}$, hal 6.

11 Ophi Khopiatuziadah, Perlindungan Konsumen Dalam Kasus Vaksin Palsu Dalam Perspektif UndangUndang, Jurnal Bphn, 2016, Hal 5.
} 
Pelanggaran hukum yang dilakukan tersangka pada kasus pemalsuan dan pengedaran vaksin palsu yang juga sangat menimbulkan keresahan pada masyarakat terutama dunia tidak cukup sebatas penipuan dan pemalsuan saja, terkait pemalsuan merek sebagaimana diatur dalam KUHP (Kitab UU Hukum Pidana), dan juga melanggar UU No 36 tahun 2009 tentang Kesehatan dan UU No 8 Tahun 1999 tentang Perlindungan Konsumen.

Mengenai perlindungan konsumen terhadap produk palsu, dengan jelas dituangkan pada Pasal 4 UU yang menjelaskan akan hak-hak yang seharusnya di dapat oleh konsumen. Pada UU yang sama juga disebutkan kewajiban pelaku usaha untuk melindungi konsumen dari adanya produk palsu. ${ }^{12}$

Pada Pasal 7 dijelaskan juga mengenai kewajiban dan tanggung jawab dari pelaku usaha terhadap produk yang dihasilkannya. Pada kasus vaksin palsu tersebut, hubungan yang terjadi tidak hanya melulu antara konsumen dan pelaku usaha atau penyedia produk farmasi namun juga pihak rumah sakit.

Selanjutnya mengenai proses penyelenggaraan upaya kesehatan berupa vaksinasi tersebut juga melibatkan banyak pihak termasuk tenaga kesehatan lain seperti dokter, perawat dan lain sebagainya yang turut andil menggunakan sediaan vaksin dengan jenis dan merek tertentu. Dalam kasus ini, ada lisensi profesi dan tanggung jawab besar yang dipertaruhkan oleh banyak pihak tenaga kesehatan. Untuk itu maka ketentuan mengenai hukum yang mengikat para pelaku usaha di bidang farmasi lebih di perketat dan di pertegas guna menerapkan sanksi yang patut diberikan bagi pelanggar peraturan dan UU tersebut. Peraturan itu meliputi Pasal 8 ayat (1), (2), dan (3) UU Perlindungan Konsumen yang didalamnya sudah dijelaskan secara rinci apa-apa saja hak-hak yang di dapatkan oleh konsumen dari pelaku usaha beserta sanksi pelanggaran yang dijelaskan pada pasal 62 UU tentang Perlindungan Konsumen. ${ }^{13}$

Adapun Penerapan Hukuaman yang ada serta contoh kasus terkait penyebaran vaksin palsu dapat di lihat pada studi putusan Nomor 1508/Pid.Sus/2016/Pn Bks dimana majelis hakim pada putusan tersebut menerapkan Pasal 197 UU No 36 tahun 2009 tentang Kesehatan dengan amar putusan menjatuhkan hukuman pidana penjara selama 9 tahun pada para terdakwa.

Penerapan dan pertimbangan hakim mengenai pertanggungjawaban pidana para pelaku tindak pidana penyebaran vaksin palsu di dalam putusan No 1508/Pid.Sus/2016/Pn Bks sudah sangat tepat karena sudah sangat sesuai dengan unsur-unsur yang di kenakan, putusan tersebut di harapkan mampu menimbulkan efek jera dan merupakan suatu peringatan preventif bagi para pelaku penyebaran vaksin palsu lainnya. Dan diharapkan mempunyai efek jera kepada terdakwa agar tidak mengulangi perbuatannya lagi.

\section{Kesimpulan dan Saran}

\subsection{Kesimpulan}

1. Pengaturan Hukum Tentang Penggunaan Vaksin Di Masyarakat di atur dalam UU No. 36 Tahun 2009 mengenai Kesehatan dan PERMENKES RI No. 12 Tahun 2017 mengenai Penyelenggaraan Imunisasi dan perlindungan konsumen dari penggunaan vaksin palsu dalam masyarakat yang dapat dimonitori oleh pemerintah melalui

\footnotetext{
${ }^{12}$ Ophi Khopiatuziadah, Op. cit, hal 6.

13 Ibid.
} 
pengawasan produk vaksin dan didalam undang-undang tersebut sudah dipaparkan secara tegas sanksi pidana yang akan didapatkan jika menyebarkan vaksin palsu.

2. Upaya Pemerintah Dalam Menanggulangi Vaksin Palsu Yang Terjadi Di Masyarakat ialah dengan mengoptimilisasi peran BPOM di dalam Pengawasan peredaran vaksin dengan meperketan izin dan melaksanakan sidak langsung ke lapangan kepada industri maupun penyedia vaksin.

3. Perlindungan hukum terhadap penyebaran vaksin palsu yang ada di masyarakat ialah dengan menerapkan sanksi pidana terhadap para pelaku penyebaran vaksin palsu yang berdasarkan pasal 196 UU No. 36 tahun 2009.

\subsection{Saran}

1. Pengaturan hukum di masyarakat belum efektif khususnya terkait vaksin palsu, berdasarkan hal itu pemerintah harus berfokus pada penerapan hukum bedasarkan kerberlakuan UU No. 36 Tahun 2009 mengenai Kesehatan yaitu tentang penyebaran vaksin palsu sehingga mampu mempersempit ruang gerak para pihak yang memproduksi dan menyebarkan vaksin palsu dalam masyarakat.

2. Bagi BPOM dan penegak hukum agar secara tergas dan secara preventif mampu mengantisipasi dan mengawasi peredaran vaksin khususnya di rumah sakit dan apotek.

3. Perlindugan hukum terhadap masyarakat atas penyebaran vaksin palsu lebih ditingkatkan tingkat efektifitasnya pasal 197 UU No. 36 Tahun 2009 mengenai kesehatan bahwa pelaku penyebaran dapat dimintakan pertanggungjawaban secara pidana, dengan demikian para pelaku penyebaran memiliki efek jera sehingga tidak lagi dapat melakukan kesalahan yaitu menyebarkan vaksin palsu yang menganggu kesehatan masyarakat.

\section{DAFTAR PUSTAKA}

Hendrik, Etika \& Hukum Kesehatan, Nuha Medika, Jakarta, 2011.

J. B. Suharjo B. Cahyono, Sp. PD,Vaksinasi Cara Ampuh Cegah Penyakit Infeksi, Kanisius, Yogyakarta, 2018.

Zaine Ashadie, Aspek-Aspek Hukum Kesehatan di Indonesia, Rajwali Press, Jakarta, 2017.

Ahmad Ramali dan Pamoentjak, Kamus Kedokteran, Erlangga, Jakarta, 2005.

Maskawati, SH., MH, Hukum Kesehatan Dimensi Etis dan Yuridis Tanggungjawab Pelayanan Kesehatan, Litera, Yogyakarta, 2018.

Roeslan Saleh, Pikiran-Pikiran Tentang Pertanggung Jawaban Pidana, Cetakan Pertama, Jakarta, Ghalia Indonesia. 
Agus Rusianto, Tindak Pidana dan Pertanggungjawaban Pidana, Kenana, Jakarta, 2016.

Kamisa, Kamus Besar Bahasa Indonesia, Cahaya Agency, Surabaya, 2012.

Dr. Putu Mastiningsih, S. ST., S. H., M. Biomed, Buku Ajar Imunisasi, IN MEDIA, Bogor, 2014.

Jurnal Kementrian Kesehatan, Kewajiban Negara Memberikan Vaksinasin dan Imunisasi, Vol 1, No. 2, 2012.

Maskawatidan, Andriani Misdar, "Hukum Kesehatan Dimens Etis dan Yuridis Tanggung jawab.

Pelayanan Kesehatan", Pertanggungjawaban Pidana terhadap Tindak Pidana penyebaran vaksin palsu pada masyarakat, Jurnal Unpad, No. 12, 2018.

Ophi Khopiatuziadah, Perlindungan Konsumen Dalam Kasus Vaksin Palsu Dalam Perspektif Undang-Undang, Jurnal Bphn, 2016.

Undang-Undang Nomor 36 tahun 2009 tentangKesehatan.

Undang-Undang Nomor 8 Tahun 1999 tentang Perlindungan Konsumen. 